\title{
Article
}

\section{Children and Domestic Homicide}

Stanley, Nicky, Chantler, Khatidja and Robbins, Rachel

Available at http://clok.uclan.ac.uk/22305/

Stanley, Nicky ORCID: 0000-0002-7644-1625, Chantler, Khatidja ORCID: 00000001-9129-2560 and Robbins, Rachel ORCID: 0000-0002-6207-7703 (2019) Children and Domestic Homicide. The British Journal of Social Work, 49 (1). pp. 59-76. ISSN 0045-3102

It is advisable to refer to the publisher's version if you intend to cite from the work. http://dx.doi.org/10.1093/bjsw/bcy024

For more information about UCLan's research in this area go to http://www.uclan.ac.uk/researchgroups/ and search for <name of research Group>.

For information about Research generally at UCLan please go to http://www.uclan.ac.uk/research/

All outputs in CLoK are protected by Intellectual Property Rights law, including Copyright law. Copyright, IPR and Moral Rights for the works on this site are retained by the individual authors and/or other copyright owners. Terms and conditions for use of this material are defined in the policies page.

\section{CLoK}

Central Lancashire online Knowledge www.clok.uclan.ac.uk

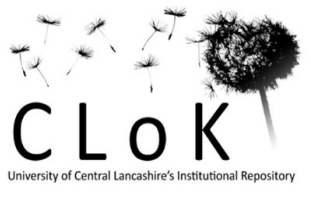




\section{Children and Domestic Homicide}

\section{Nicky Stanley, Khatidja Chantler and Rachel Robbins}

School of Social Work, Care and Community, University of Central Lancashire, Preston PR1 2HE, UK.

Lead author: Nicky Stanley

Email: NStanley@uclan.ac.uk

Corresponding Author:

Professor Nicky Stanley

School of Social Work, University of Central Lancashire, Preston PR1 2HE

UK

Email: NStanley@uclan.ac.uk

Telephone: 00441772893655

Fax: 00441772892974 